\title{
ETHNOBOTANICAL STUDY OF MEDICINAL PLANTS OF RESUNGA HILL USED BY MAGAR COMMUNITY OF BADAGAUN VDC, GULMI DISTRICT, NEPAL.
}

\author{
RajendraAcharya* \\ *Madan Bhandari Memorial College, Binayak Nagar, New Baneshwor, Kathmandu, Nepal.
}

\begin{abstract}
Present study aims to explore the ethnobotanical information on medicinal plants used by Magar community of Badagaun VDC of Gulmi district. The study was carried out during different periods of the year 2010. Informations on plant and plant parts uses were collected interviewing key informants by using semi-structured open-ended questionnaire. Altogether 161 different plant species belonging to 87 familes and 144 genera were documented and majority of them are herbs. In terms of plant parts use, leaf and stem/bark are in top priorities. These plants are used to treat different ailments ranging from gastro-intestinal to headache and fever, respiratory tract related problems to dermatological problems, snake bite to ophthalmic and cuts and wounds. Easy access to modern medicines and less recognition of traditional healers are the main causes leading to decrease in interest of young generation in the use of traditional medicinal practices.
\end{abstract}

Keywords: Ethnobotany; Medicinal plants; Resunga hil;, Magar community.

\section{INTRODUCTION}

Today, ethnobotany plays a crucial role in the study of traditional medicine, as it has an interfacial function linking nature with culture and traditional knowledge with modern technology thus contributing to all understanding of traditional medicinal knowledge (Pei, 2005). The main aim of ethnobotany is to document the knowledge about plants that have come through generations and use the knowledge for the benefit of the society (Chaudhary, 1998). The ethnic communities have significant customary knowledge on utilization of plant and plant parts and there is a long tradition of transferring this indigenous knowledge from generation to generation (Acharya and Acharya, 2009). Use of plants for curing diseases was common in most parts of the world for a long time. Of the 75,000 plants used in different systems of medicine, more than 20,000 species of higher plants are used in the traditional treatment practices of indigenous cultures living around the world (Ved Prakash, 1998). Therefore, medicinal plants or plant derived medicines have always played a key role in world health including the maintenance of health as well as in the introduction of new treatment. The world health organization (WHO) has estimated that about $80 \%$ of the population in developing countries depend on traditional medicine for their primary heath care needs. Many such plants also have other domestic uses. It is therefore very important that studies in ethnobotany and ethnopharmacology continue so as to preserve traditional knowledge (Kurmi and Baral, 2004).

Nepal is rich in biological resources and particularly well known for medicinal and aromatic plants; it is necessary to investigate the medicinal value of Nepalese medicinal and aromatic plants which might have tendency to influence human biochemistry since plant species being used as traditional herbal medicine (Singh, 2006). In Nepal, about 7080 percent of population in the mountain region depend on traditional medicines for health care (Manandhar, 1980). Medicinal plants have been in use traditionally for times immemorial and have been serving the mankind. Recently updated database revealed a total of 1950 species of medicinal plants used in Nepal and out of which 1906 species are identified under vascular groups comprising 1614 native,192 introduced and/cultivated and 100 naturalized taxa (Ghimire, 2008). Majority of such valuable plants grow in wild conditions as natural components of vegetation of different regions of Nepal from tropical to sub tropical and temperate to alpine climatic conditions. The plant and plant resources for medicinal use are collected by local people and herbal healer from various habitats such as forest, scrubland, grassland and cultivated fields and use them as crude drugs. It is known that the way of administration to cure disease using a particular plant widely differs among the indigenous people and also healers, jhakris and amchies (homeopathic/ayurvedic doctors) (Manandhar, 2002; Shrestha and Dhillion, 2002). These plants has also become the important source of medicine for the local healers in the villages as well as the basic raw materials for Ayurvedic, Tibetan, homeopathic and allopathic medicines (Ghimire et al., 1999). It is a fact that a large number of medicinal plants and associated indigenous knowledge on their uses still remain without proper documentation (Chaudhary, 1998) although many traditional

Author for correspondence: Rajendra Acharya, Madan Bhandari Memorial College, Binayak Nagar, New Baneshwor, Kathmandu, Nepal. E-mail: acharya.raj2010@gmail.com. 
systems of medicine are now being gradually documented in Nepal. So, the priority should be given to the documentation of indigenous knowledge and conservation of the existing species and inhabitants before some of these are eliminated from the area (Joshi et al., 2003).

Magar community or Magars is known as a ShinoTibetan ethnic group whose homeland mainly extend from the western and southern part of Dhaulagiri to the Mahabharat mountains and the Siwalik foothills and eastward into the Gandaki basin. According to Nepal census 2001, 1.6 million people identified themselves as belonging to the Magar ethnolinguistic group, representing $7 \%$ of Nepal's population and making them the largest indigenous ethnic group in the country (CBS, 2002). They have cultural diversity within and among communities. Cultural diversity often follows the patterns of biophysical diversity because of the intimate relationship between people and plant resources which has led to the wealth of ethno- botanical knowledge associated with plant resources in their use for food, fiber and medicine (Ale et al., 2009).

Despite advances in modern technologies, ethnobotanical knowledge is still used in Magar community of Nepal and rests primarily in older generations vaidyas, kabirajs, dhamis and jhankris (traditional healers). The traditional healing practice of the Magars is limited to certain key member of the society, they communicate these knowledge orally from generation to generation. In this context, very few sporadic works have been already done to collect the ethnobotanical data and traditional knowledge systems of Magar community (Mahato, 1998; Ale et al., 2002; Poudel and Gautam, 2008). The ethnobotanical information of Magar community of Badagaun VDC is still undocumented,
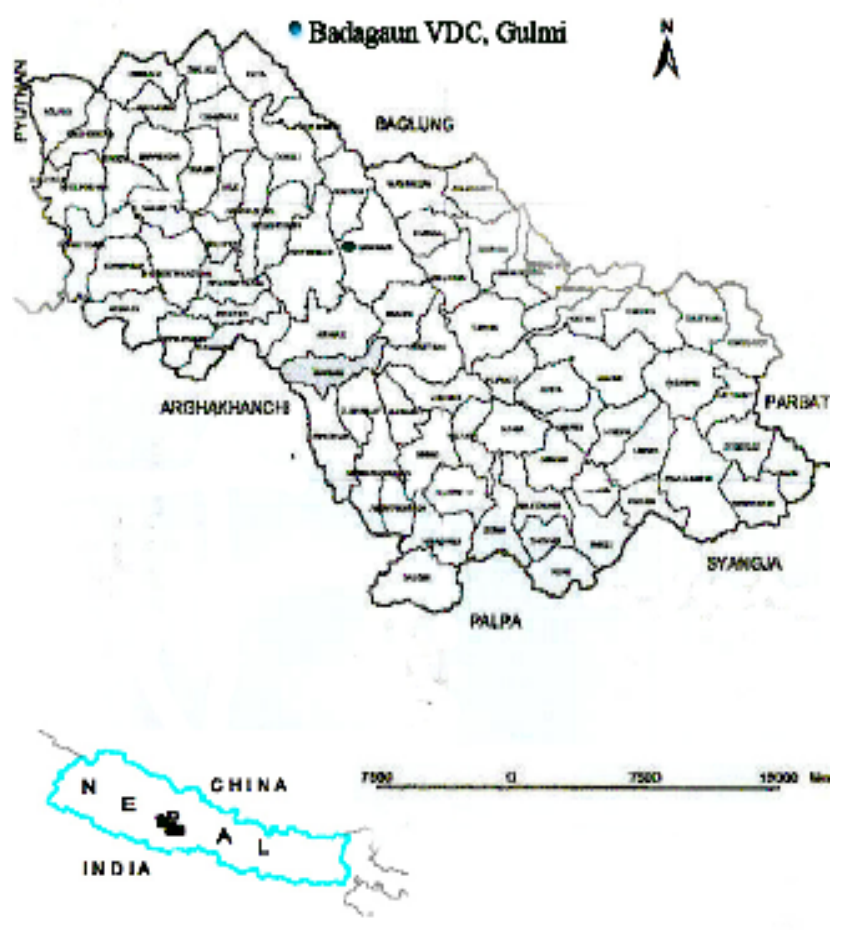

however utilization of plant resources of Resunga forest area by local people of eleven VDCs of Gulmi district was already done by KC (2006). In this background present study was devised to document the traditional knowledge on medicinal plants with their indigenous uses and practices.

\section{Materials and Methods \\ Study Area}

Badagaun VDC is located in Gulmi district, which lies between $27^{\circ} 55^{\prime}$ to $28^{\circ} 27^{\prime} \mathrm{N}$ latitude and $83^{\circ} 10^{\prime}$ to $83^{\circ} 35^{\prime} \mathrm{E}$ longitude. Gulmi is one of the hilly district of western development region of Nepal and covers a total area of about 107918.2 ha of which about $50.2 \%$ agricultural land, $11.8 \%$ grazing land, 37.6\% forest and Shrubland, 0.4\% landslide area and others (sand, concrete, rocks) $0.7 \%$ (Nepal, 2003). The altitude of the district ranges from $465 \mathrm{~m}$ to $2690 \mathrm{~m}$ asl. and most of the area in the district belongs in the Mahabharat range. Present study was carried out on Resunga hill which covers a total area of about 3400 ha. The altitude of the Resunga hill varies from $700 \mathrm{~m}$ (Chhaldi khola) to 2350m asl. Out of 3400ha forest land of Resunga, 1973.93ha is covered by eighteen community forest and is managed by community and the rest area is under government managed. The mountain is known for the place of historical and religious importance where a sage by the name of 'Rishya Shringa' is supposed to be observed meditation in the long past and as the time passed on the word 'Rishya Shringa' changed to 'Resunga' (Subedi, 1998). Resunga, a natural forest block with historically and religiously importance place, which is surrounded by elevennVDCs. Different temples with religious importance like Siddhababa, Bishnu Paduka, Radha Krishna, Siwalayas, Yagyashala (hall for worshiping), Gaushala (cowshed)' Samadhisthal (grave stone) of Shashidhar (a renowned sage), still prove the Resunga as a place ofb religious, historical and archeological importance (Khadka and Pokharel, 1999) and monasteries are situated on the top of the forest where every year in Harisayani, Haribodhani, Akadashi and throughout the shrawan month people come to worship and bath in the Resunga pond situated within the forest (Nepal, 2003). At the base of Resunga peak, headquarter of the district-Tamghas is situated. Local inhabitants are benefitted from the mountain directly or indirectly for their both major and minor forest products. Besides forest products about 252 watersheds have been estimated in the Resunga area (Panthi, 1984); which is also the resource of drinking water for several VDCs. The forest is being traditionally used for timber, fodder, fuel wood, leaf litter, medicinal herbs, etc. (KC, 2006). The study area is dominated mainly by three ethnic groups Magar, Brahmin and Chhetri and a number . of other ethnic groups like Kami, Sarki, Damai and Newar. The total population of Badagaun VDC is about 8430 accounting 1550 household (HH) of which about 2215 are Magar (Anonymous, 2009). Landscapes of Resunga is very rich in biodiversity with great variation in vegetation housing sub-tropical to lower temperate regions flora accompanied by sub tropical and temperate types nof forest which consists of Schima - Castanopsis, Pinus roxburghii, Quercus semecarpifolia, Rhododendron arboretum, Pyrus pashia, Aesculus Pinus roxburghi indica, Myrsine capitellata, etc. (Khadka and Pokhrel). . The climate 
of the study area is typically sub tropical to temperate type with cool and humid climate. The average temperature is maximum $26^{\circ} \mathrm{C}$ and minimum $4.1^{\circ} \mathrm{C}$ and it receives average annual rainfall of about 1,939mm (GoN, 2008). Castanopsis, , Quercus semecarpifolia, Rhododendron arboretum,

\section{FIELD STUDY}

The study area was surveyed during different periods of the year 2010. Information on plant and plant parts uses was collected by interviewing key informants using a semistructured open-ended questionnaire. The selected ward for interview were ward number 1,2,3 \& 4 of Badagaun VDC. To collect plant species for herbarium preparation, key informants were employed. Some of the collected specimens were identified in the field, whereas others were identified with the help of standard literature (Hara et al.,1978,1982; Hara and Williams, 1979; Polunin and Stainton, 1984; Stainton, 1988) and with cross checking the specimens deposited at Tribhuvan University Central Herbarium (TUCH), Kirtipur while some of them were identified with the help of experts of taxonomy. The nomenclature of the identified species and their family names follows Hara et al. 1978 \& 1982, Hara and Williams (1979) and Press et al. (2000).

\section{RESULT AND DISCUSSION}

We collected informations on 161 medicinal plant species which fall under 144 genera and 87 families. Among them 152 species are angiosperms, six species are pteridophytes, two species are lichens and one speices of gymnosperm. List of medicinal plants with their scientific name, family, collection number, local name, life form, parts used and uses are presented in table 1 . The species are arranged alphabetically. Out of total species used for medicinal value, majority are herb (39\%) followed by tree (26\%), shrub (24\%) and climber (11\%) (figure 2). However, herbaceous species were most commonly used which may be due to easy to collect, store and transport or easily available. The family Labiatae is represented by the highest number of species (eight species) followed by Leguminosae, Poaceae (seven species each), Euphorbiaceae, Lauraceae (five species each),

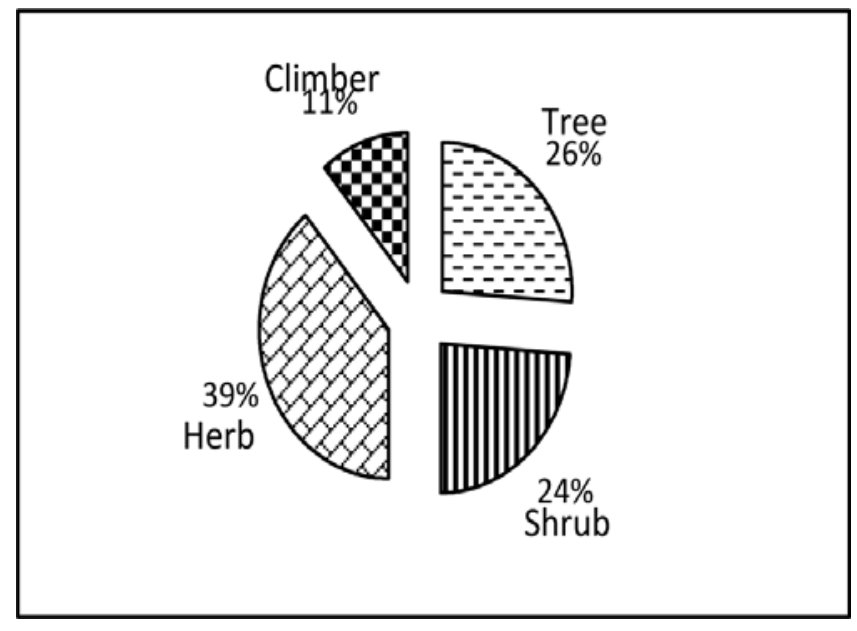

Fig. 2: Different life forms of medicinal plants collected.

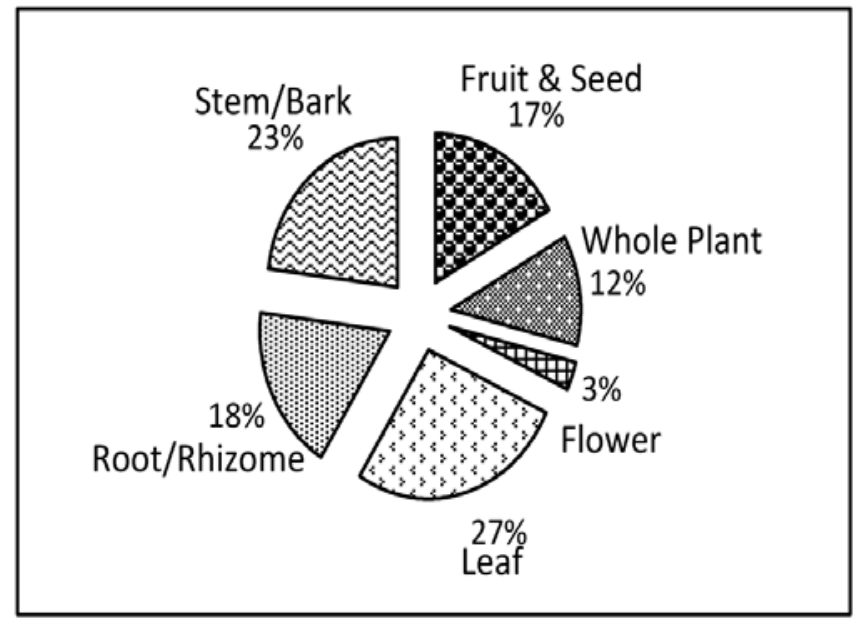

Fig. 3: Graph showing plant and plant parts used

Ranunculaceae, , and Zingiberaceae (four species each), Anacardiaceae, Dioscoreaceae, Ericaceae, Myrtaceae, Solanaceae and Saxifragaceae (three species each) and Amaranthaceae, Amaryllidaceae, Araceae, Combretaceae, Gentianaceae, Liliaceae, Menispermaceae, Oxalidaceae, Piperaceae, Thymelaceae and Valerianaceae (two species each) . The study shows more or less similar results with those reported in an earlier studies in Palpa district (Shrestha et al., 2004; Ale et al., 2009), Dhading district (Poudel and Gautam, 2008), Arghakhanchi district (Poudel et al., 2010), Salyan district (Kurmi and Baral, 2004) and Sindhupalanchok district (Rai et al., 2004). Out of 161 species documented for medicinal use in the present study area, 72 species are reported by Ale et al. (2009), 60 species by KC(2006), 61 species by Poudel et al.( 2010), 47 species by Kurmi and Baral (2004) and 30 species by Shrestha et al. (2004). But 23 species reported in this study have not been reported in above mentioned references.

Different parts of the plants are used to treat various ailments at the local level. The plant parts widely used for medicinal purposes include leaf and stem/bark are used (each being $27 \%$ and $23 \%$ respectively) followed by root/rhizome, fruit and seed (each bearing nearly equal 18\% and $17 \%$ respectively), whole plant (12\%) and least the flower (3\%) (figure 3).

Regarding different disease categories, we found that 57 medicinal plant species used to treat gastro-intestinal problems (dysentery, diarrhea, gastritis, abdominal pain, ulcer, etc.), 38 species are used to treat headache, toothache, joint pain, fever, etc, 27 species are used to treat for respiratory tract related problems (cough/cold, bronchial problem, sore throat, asthma, etc), 20 species for ophthalmic and cuts and wounds, 16 species are used to cure dermatological problems (scabies, burns, swellings and other skin related problems) and very less (3 species) for snake/scorpion bite (Table 1). This result indicated that Magar people have retained indepth knowledge of medicinal values of plants. In response to the question regarding the prevalent diseases in the study area vaidyas responded that major diseases are typhoid, jaundice, dysentery, diarrhea and gastritis, etc. For the purposes to 
treat the diseases, various forms of preparation were used. The most popular medicinal preparations usedb were in the form of powder, paste, decoction and juice. Some of the plant species available were not used alone as medicine but were used by mixing with other herbs in specific amounts. Some medicinal plants such as Maesia chisia, Sapindus mukorossii, Entada phasioloides and Agave cantula are also used in fish poisoning or fishing. On the other hand, certain medicinal plants like Arisaema tortuosum, Justicia adhatoda, Osyris wightiana and Artemisia vulgaris are used as green manuring in agricultural land and pesticides as well. From this research work, it was found that one plant has curative properties against different types of diseases and even a single disease can be cured by different medicinal plants where as use of individual medicinal plants to cure a single disease was less in number. Out of 161 plant species, 27 species have single use whereas 134 species have two or more uses (Table 1).

Although modern systems of remedy like allopathy, surgery are common in practice in the cities and town and a few remote areas of Nepal, most of the rural people rely up on the nature to fight against the germs and worms even today. Certainly the crude plants and plant products are less potent than modern medicines which have been introduced by passing a series of examinations (Rai et al., 2004). However, local healers, local people and patients are not well informed about the chemical nature of plants and plant products, which may even be fatal. There is common belief that medicine from plant sources have no side effects. But it is remarkable that there are some toxic plants which are more hazardous and may be fatal if administered by unknowledgeable person or learner healer or taken crude (Rai and Pokhrel, 2006). It may be true that most of the plant based medicines have fewer side effects. This study showed that the elderly persons/ traditional healers have greater knowledge upon the utilization of medicinal plants in comparison to younger generations. During field work we found that women know more herb species than men. This may be due to their role in collecting grass as fodder to feed their cattles. I also found that they were not comfortable to share their knowledge to other people. The knowledge of plant availability, collection time, method of preparation, disease diagnosis and prescribed uses was limited to their some senior family members only.

During our study period, I found some cases that the people are seeking help from the traditional healers when their illness was not cured by modern medicines. Except highly communicable diseases and emergency cases, people of the study area still depend on traditional medicinal practices in the treatment of various common diseases such as dysentery, diarrhea, stomach problem, gastritis, jaundice, skin related problems, etc. The dependence of people on these plants for health care is associated with their tradition belief on the effectiveness for curing ailments rather than just poverty. When we interacted with younger generation of the society, they showed less interest in traditional practices mostly because of poor recognition of traditional healers and availability of modern health facilities such as ayurvedic clinics, hospitals and health centers are located in the headquarter of the district near to the study area (about $16 \mathrm{~km}$ far from the headquarter). Although there was high use of plant resources in community level, the indigenous knowledge about medicinal plants seems depleting generation to generation.

The retardation of traditional knowledge on medicinal plants may be due to lack of successor of faith healers, wider use of modern medicine and inadequacy of plants availability (Mardar and Chaudhary, 1992). There is lack of continuation and flow of indigenous knowledge from elder to younger generation, since the young generations are reluctant to learn about the traditional practices. Therefore, there is great chance of decline of the wealth of knowledge (KC, 2006). The trend of disinterest of young generation shows that the traditional knowledge on medicinal plants is deteriorating in present study area. It is important to share the knowledge and experiences from older to younger generations. This knowledge can be the valuable assets for future generation and economic development of the community. The emphasis should also be given on wide cultivation of medicinal plants which are in pressure of excessive harvesting and are medicinally more valuable. To preserve these valuable natural resources first these existing valuable information are needed to be documented before they are lost or disappeared. Unfortunately little knowledge of this important resource, unscientific collecting practices, lack of awareness in harvesting, regulation, conservation, cultivation, proper use and importance of a variety of herbs and shrubs amongst the community, many valuable species of medicinal plants have already become extinct and many more are endangered. Some valuable medicinal plants are in threatened condition. On the basis of interview taken with local pdeople and fields observation, some of the medicinal plant like Aconitum ferox, Paris polyphylla, Sapindus mukorosii and Valeriana jatamansii have been to be significantly decreased in these days in comparison to earlier days (about 25 years ago) (Khadka and Pokharel, 1999), which may be due to indiscriminate harvesting without sustainable management like immature collection, uprooting of underground parts and over exploitation. Strong emphasis should be given for the documentation of indigenous uses, traditional knowledge and practices. Besides documentation, biochemical analysis (i.e. phytochemistry) of the documented plant species and ecological study of the particular medicinal plants is also essential to check the reliability and validity of current finding and to know their diversity as well.

\section{CONCLUSION}

Present study shows that the study area is rich in various types of valuable medicinal plants. Magar community has a good ethnobotanical knowledge in using plant resources and developed their own traditionalsystem of using plants for medicinal uses. Specially, the elderly people of a community and the local traditional healers have greater knowledge on medicinal plants. But the youngsters of the study area showed less interest in traditional practices mainly due to less recognition of traditional healers and easy availability of modern medicines and instant effect. Because of which the practice of using plants and plants parts for medicinal use is decreasing. So the emphasis should be given for the 
Table 1: List of medicinal plant with their scientific name, family and collection number with their local name, life form, parts used and uses.

\begin{tabular}{|c|c|c|c|c|c|}
\hline SNo. & $\begin{array}{l}\text { Plant species, Family and } \\
\text { Voucher number }\end{array}$ & Local name & $\begin{array}{l}\text { Life } \\
\text { form }\end{array}$ & Parts used & Uses \\
\hline 1. & $\begin{array}{l}\text { Acorus calamus L. ARACEAE } \\
\text { RA } 84\end{array}$ & Bojho & $\mathrm{H}$ & Rhizome & $\begin{array}{l}\text { Rhizomes are chewed to cure cough and cold. The crushed rhizome is } \\
\text { used to cure gout, epilepsy. }\end{array}$ \\
\hline 2. & $\begin{array}{l}\text { Aconitum ferox wall. ex Ser } \\
\text { RANUNCULACEAE } \\
\text { RA } 89\end{array}$ & Bikhma (M) & $\mathrm{H}$ & Whole plant & $\begin{array}{l}\text { Whole plant is crushed to make powder or decoction which is used to } \\
\text { cure fever, nausea and vomiting, however taking large quantity may be } \\
\text { fatal. }\end{array}$ \\
\hline 3. & $\begin{array}{l}\text { Achyranthes aspera } \mathrm{L} \text {. } \\
\text { AMARANTHCEAE } \\
\text { RA } 75\end{array}$ & Ulteyannash (M) & $\mathrm{H}$ & $\begin{array}{l}\text { Leaf, stem and } \\
\text { root }\end{array}$ & $\begin{array}{l}\text { Paste of leaf is applied to cure boils, juice of stem and root is diuretic, } \\
\text { laxative, expectorant, stomachic, haementinic. }\end{array}$ \\
\hline 4. & $\begin{array}{l}\text { Adiantum cappillusverneris } \mathrm{L} \text {. } \\
\text { ADIANTACEAE } \\
\text { RA } 82\end{array}$ & Unyu & $\mathrm{H}$ & Root & Root juice is taken in migraine, snakebite and scorpion sting. \\
\hline 5. & $\begin{array}{l}\text { Aegle marmelos (L.) Correa } \\
\text { RUTACEAE } \\
\text { RA } 155\end{array}$ & Bel & $\mathrm{T}$ & Ripe fruit & $\begin{array}{l}\text { Used to treat diarrhoea and dysentery. Also cure hotness of body, heart } \\
\text { tonic. The unripe fruit is astringent, stomachic and digestive. A sharbat } \\
\text { (juice) of the ripe fruit is given for chronic constipation and dyspepsia. }\end{array}$ \\
\hline 6. & $\begin{array}{l}\text { Aesculus indica (Colebr. ex } \\
\text { Cambess.) Hook. } \\
\text { HIPPOCASTANACEAE } \\
\text { RA } 63\end{array}$ & Lekh pangro & $\mathrm{H}$ & Root & $\begin{array}{l}\text { Root is crushed to make power or decoction which is used to cure } \\
\text { typhoid. }\end{array}$ \\
\hline 7. & $\begin{array}{l}\text { Agave cantula Roxb. Ex Salm- } \\
\text { Dyck } \\
\text { AGAVACEAE } \\
\text { RA } 157\end{array}$ & Hattibar (M) & $\mathrm{H}$ & Leaf & $\begin{array}{l}\text { Leaf juice with jaiphal (Myricaria germanica) oil is massaged to cure } \\
\text { sprain. Leaf juice is also used in fish poisoning or fishing. }\end{array}$ \\
\hline 8. & $\begin{array}{l}\text { Ageratum conyzoides L. } \\
\text { COMPOSITAE } \\
\text { RA } 197\end{array}$ & Gandhe jhar & $\mathrm{H}$ & Leaf & Leaf juice is applied over cut wounds to stop bleeding. \\
\hline 9. & $\begin{array}{l}\text { Allium wallichi Kunth } \\
\text { AMARYLLIDACEAE } \\
\text { RA } 149\end{array}$ & Ban lasun & $\mathrm{H}$ & Bulb & $\begin{array}{l}\text { Used to treat headache, backbone pain, arthritis, sprain, kidney problem, } \\
\text { stomach problem. }\end{array}$ \\
\hline 10. & $\begin{array}{l}\text { Almus nepalensis D.Don } \\
\text { BETULACEAE } \\
\text { RA } 36\end{array}$ & Utis & $\mathrm{T}$ & Bark & $\begin{array}{l}\text { The concentrated decoction of mature bark is applied on the wounds. A } \\
\text { powder of the bark is applied to cure scabies. }\end{array}$ \\
\hline 11. & $\begin{array}{l}\text { Aloe vera }(\mathrm{L} .) \text { Burm } \mathrm{f} \text {. } \\
\text { ASPHODELACEAE } \\
\text { RA } 80\end{array}$ & Ghiukumari & S & Leaf & Cure burn wounds, regulation of menstruation, constipation, ascariasis. \\
\hline 12. & $\begin{array}{l}\text { Alternatherea sessile ( L.) DC. } \\
\text { AMARANTHACEAE } \\
\text { RA } 141\end{array}$ & Bhirangi jhar & $\mathrm{H}$ & Leaf & Leaf juice is used to cure cut wounds. \\
\hline 13. & $\begin{array}{l}\text { Ampelocissus divaricata (Wall. } \\
\text { ex M.A Lawson) Planch. } \\
\text { VIOLACEAE } \\
\text { RA } 34\end{array}$ & Pureni & $\mathrm{C}$ & Stem & Used to treat eye disease. \\
\hline 14. & $\begin{array}{l}\text { Anagallis arvensis L. } \\
\text { PRIMULACEAE } \\
\text { RA } 168\end{array}$ & Armale & $\mathrm{H}$ & Whole plant & Used to cure stomach-ache and gastritis, indigestion. \\
\hline 15. & $\begin{array}{l}\text { Anemone rivularies Buch.-Ham. } \\
\text { ex DC. } \\
\text { RANUNCULACEAE } \\
\text { RA } 77\end{array}$ & Kangreshi jhar & $\mathrm{H}$ & Root & Decoction of root is given to cure typhoid. \\
\hline 16. & $\begin{array}{l}\text { Anemone tetrasepala Royale } \\
\text { ANUNCUACEAE } \\
\text { RA } 150\end{array}$ & Kaude & $\mathrm{H}$ & Root & Root juice is used to cure stomachic problem \\
\hline 17. & $\begin{array}{l}\text { Arisaema tartuosum (Wall.) } \\
\text { Schott } \\
\text { ARACEAE } \\
\text { RA } 85\end{array}$ & $\begin{array}{l}\text { Sarpako makai } \\
\text { (M) }\end{array}$ & $\mathrm{H}$ & Whole plant & Used to cure wounds and blisters (khatira). Also used as insecticides. \\
\hline 18. & $\begin{array}{l}\text { Artemisia vulgaris L. } \\
\text { COMPOSITAE } \\
\text { RA } 156\end{array}$ & Patik (M) & $\mathrm{H}$ & Leaf & $\begin{array}{l}\text { Leaf juice is used to stop bleeding on cut wounds, scabies, gastritis, } \\
\text { asthma and asscariasis. }\end{array}$ \\
\hline 19. & $\begin{array}{l}\text { Artocarpus lakoocha Wall. ex } \\
\text { Roxb. MORACEAE } \\
\text { RA } 30\end{array}$ & Badahar & $\mathrm{T}$ & Bark & Latex of bark is used to cure boils and blister (khatira). \\
\hline 20. & $\begin{array}{l}\text { Arundinaria sp. POACEAE } \\
\text { RA } 137\end{array}$ & Nigalo & S & Root & $\begin{array}{l}\text { Root juice is anthelmintic and is also used to cure gastritis, balancing } \\
\text { hotness and coldness in the body. }\end{array}$ \\
\hline 21. & $\begin{array}{l}\text { Asparagus racemosus Willd. } \\
\text { LILIACEAE } \\
\text { RA } 167\end{array}$ & Bhik (M) & S & Root tuber & Used to increase lactation in delivered woman and tonic. \\
\hline 22. & $\begin{array}{l}\text { Astibile sp. SAXIFRAGACEAE } \\
\text { RA } 78\end{array}$ & Gujargano & $\mathrm{C}$ & Root tuber & Used to treat headache, stomach-ache, ascariasis, gastritis. \\
\hline 23. & $\begin{array}{l}\text { Astibile rivularis } \text { Buch.-Ham.ex } \\
\text { D. Don } \\
\text { SAXIFRAGACEAE. } \\
\text { RA } 159\end{array}$ & Thulo okhati & S & Root & $\begin{array}{l}\text { Root juice is taken for appetizer, to check vaginal bleeding in pregnant } \\
\text { woman, tonic in post delivery, disorder of menstruation, diarrhoea, } \\
\text { dysentery and hemorrhage. Powder of root is mixed with soaked seeds } \\
\text { of Trigonella foemumgracium (methi) \& is taken with milk or jad } \\
\text { (locally prepared drug) to cure rheumatism. }\end{array}$ \\
\hline 24. & $\begin{array}{l}\text { Bauhinia vahlii Wight \& Am. } \\
\text { LEGUMINOSAE } \\
\text { RA } 23\end{array}$ & Bhorla (M) & $\mathrm{C}$ & Bark & Bark juice is used to cure dysentery and stomach-ache. \\
\hline 25. & $\begin{array}{l}\text { Bauhinia variegata } \mathrm{L} \text {. } \\
\text { LEGUMINOSAE } \\
\text { RA } 86\end{array}$ & Byagan (M) & $\mathrm{T}$ & Bark/Stem & Used as antidote in snake bite. Bark juice is used to treat dysentery. \\
\hline 26. & $\begin{array}{l}\text { Begonia picta Sm. } \\
\text { BEGONIACEAE } \\
\text { RA } 29\end{array}$ & Makarkanchi & $\mathrm{H}$ & Leaf & $\begin{array}{l}\text { Paste of leaf is applied on wound between toes caused due to prolonged } \\
\text { walking on mud. }\end{array}$ \\
\hline
\end{tabular}




\begin{tabular}{|c|c|c|c|c|c|}
\hline SNo. & $\begin{array}{l}\text { Plant species, Family and } \\
\text { Voucher number }\end{array}$ & Local name & $\begin{array}{l}\text { Life } \\
\text { form }\end{array}$ & Parts used & Uses \\
\hline 27. & $\begin{array}{l}\text { Berberis aristata } \text { DC. } \\
\text { BERBERIDACEAE. } \\
\text { RA } 160\end{array}$ & Chautara (M) & $\mathrm{S}$ & Bark & $\begin{array}{l}\text { Bark juice is used to cure bile disorder; eye boils (aankha pakeko). Ripe } \\
\text { fruits are edible. }\end{array}$ \\
\hline 28. & $\begin{array}{l}\text { Berginia ciliata }(\text { Haw.) Sternb. } \\
\text { SAXIFRAGACEAE } \\
\text { RA } 198\end{array}$ & Pakhane (M) & $\mathrm{H}$ & Stem/Root & $\begin{array}{l}\text { Powder or decoction of stem/root is used to cure stone problem, burning } \\
\text { sensation of urination, sexual incapability, vaginal flowing of white } \\
\text { water, and stomach-ache during menstruation, backbone ache and tonic. }\end{array}$ \\
\hline 29. & $\begin{array}{l}\text { Betula alnoides Buch.-Ham. ex } \\
\text { D. Don } \\
\text { BETULACEAE } \\
\text { RA } 170\end{array}$ & Saur & $\mathrm{T}$ & Bark & $\begin{array}{l}\text { Bark juice is applied on cut wound to check bleeding, bone fracture, } \\
\text { sprain (sarke markema). }\end{array}$ \\
\hline 30. & $\begin{array}{l}\text { Bistorta amplexicaulis (D. Don) } \\
\text { Greene } \\
\text { POLYGONACEAE RA } 35\end{array}$ & Khaldi & $\mathrm{H}$ & Root & Root juice is used to cure scabies. \\
\hline 31. & $\begin{array}{l}\text { Bombax ceiba } \mathrm{L} \text {. } \\
\text { BOMBACACEAE } \\
\text { RA } 37\end{array}$ & Simal & $\mathrm{T}$ & Bark & Paste of bark is used to cure wound, scabies and for pimples. \\
\hline 32. & $\begin{array}{l}\text { Cassia fistula } \mathrm{L} \text {. } \\
\text { LEGUMINOSAE } \\
\text { RA } 169\end{array}$ & Rajbrikchha & $\mathrm{T}$ & Fruit, Seed & Cure hotness of body, urinary problem. \\
\hline 33. & $\begin{array}{l}\text { Calotropis gigantea }(\text { L.) Dryand. } \\
\text { ASCLEPIADACEAE } \\
\text { RA } 138\end{array}$ & Aank & $\mathrm{S}$ & Fruit, Leaf & $\begin{array}{l}\text { Used to treat body pain, sinusitis, latex of leaf is used to cure boils, } \\
\text { sprain. }\end{array}$ \\
\hline 34. & $\begin{array}{l}\text { Centella asiatica (L). Urb. } \\
\text { UMBELLIFERAE } \\
\text { RA } 108\end{array}$ & Ghodtapre & $\mathrm{H}$ & Leaf & $\begin{array}{l}\text { Leaf juice is used to cure fever, nerve troubles, enhances memory and } \\
\text { brain tonic. }\end{array}$ \\
\hline 35. & $\begin{array}{l}\text { Cheilanthus bicolor (Forss K.) } \\
\text { Kaulf } \\
\text { PTERIDACEAE } \\
\text { RA } 28\end{array}$ & Ranisinki (M) & $\mathrm{H}$ & Whole plant & Used to cure fever, gastritis, cut wounds. \\
\hline 36. & $\begin{array}{l}\text { Cinnamomum camphora }(\mathrm{L} .) \mathrm{J} . \\
\text { Presl. } \\
\text { LAURACEAE. } \\
\text { RA } 74\end{array}$ & Ban kapur & $\mathrm{T}$ & Leaf & Used to cue pneumonia, asthma. \\
\hline 37. & $\begin{array}{l}\text { Cinnamomum glaucescens } \\
\text { (Nees) Hand-Mazz } \\
\text { LAURACEAE } \\
\text {.RA } 27\end{array}$ & Malaygiri (M) & $\mathrm{T}$ & Fruit, Stem & $\begin{array}{l}\text { Fruit is used for perfumery oil production. Stem is used for the purpose } \\
\text { of chandan (substitute of srikhanda) and in treating various skin } \\
\text { diseases. }\end{array}$ \\
\hline 38. & $\begin{array}{l}\text { Cinnamomum tamala (Buch.- } \\
\text { Ham.) Nees } \\
\text { LAURACEAE. } \\
\text { RA } 38\end{array}$ & Tiji (M) & $\mathrm{T}$ & Leaf, Bark & $\begin{array}{l}\text { Used to cure stomach-ache, sexual incapability, dysentery, vomiting oil } \\
\text { is used to cure toothache. Bark and leaf also used as spices. }\end{array}$ \\
\hline 39. & $\begin{array}{l}\text { Cissampelos pareira } \mathrm{L} \text {. } \\
\text { MENISPERMACEAE } \\
\text { RA } 87\end{array}$ & Tikunthyak (M) & $\mathrm{C}$ & Leaf,Rhizome & $\begin{array}{l}\text { Leaf juice is taken with mishri (derivative of sugar) to cure jaundice. } \\
\text { Juice of rhizome is given to cure gastritis. }\end{array}$ \\
\hline 40. & $\begin{array}{l}\text { Clematis buchananiana } \text { DC. } \\
\text { RANUNCULACEAE } \\
\text { COMOSITAE } \\
\text { RA } 113\end{array}$ & Baghjunge & $\mathrm{C}$ & Leaf & $\begin{array}{l}\text { Leaf juice is applied over cut wounds to stop bleeding and can also be } \\
\text { externally applied to cure skin diseases. }\end{array}$ \\
\hline 41. & $\begin{array}{l}\text { Circium verutum (D. Don) } \\
\text { Spreng. } \\
\text { COMOSITAE } \\
\text { RA } 117\end{array}$ & $\begin{array}{l}\text { Sungure kandaa } \\
\text { (M) }\end{array}$ & $\mathrm{H}$ & Leaf & $\begin{array}{l}\text { Leaf juice is taken during stomach inflammation and burning sensation } \\
\text { of urination. }\end{array}$ \\
\hline 42. & $\begin{array}{l}\text { Clinopodium umbrossum } \mathrm{L} \text {. } \\
\text { LABIATAE } \\
\text { RA } 148\end{array}$ & Bilajor & $\mathrm{H}$ & Stem & Used to cure joint pain and sprain (sarke-markema). \\
\hline 43. & $\begin{array}{l}\text { Colebrookea oppositifolia } \text { Smith } \\
\text { LABIATAE } \\
\text { RA } 111\end{array}$ & Daksya (M) & $\mathrm{s}$ & Leaf & Decoction or powder of leaves is used to cure sinusitis. \\
\hline 44. & $\begin{array}{l}\text { Crateva unilosularis Buch.- } \\
\text { Ham. } \\
\text { CAPPARACEAE } \\
\text { RA } 109\end{array}$ & Siplican & $\mathrm{T}$ & $\begin{array}{l}\text { Tender shoot/ } \\
\text { Young leaf }\end{array}$ & Used to treat fever, stones, diabetes. Laxative, anthelmintic. \\
\hline 45. & $\begin{array}{l}\text { Crotalaria cystisoides Roxb. } \\
\text { LEGUMINOSAE } \\
\text { RA } 114\end{array}$ & Chengiphul & $\mathrm{S}$ & Seed & Used to cure fever, menstrual disorder, sterility. \\
\hline 46. & $\begin{array}{l}\text { Curcuma caesia Roxb. } \\
\text { ZINGIBERAEAE } \\
\text { RA } 147\end{array}$ & Kalo haledo & $\mathrm{H}$ & Rhizome & $\begin{array}{l}\text { Used to treat paralysis, gastritis, sprain (sarke-markema). Appetizer, } \\
\text { blood purifier. }\end{array}$ \\
\hline 47. & $\begin{array}{l}\text { Curcuma zeodarica } \text { Roxb. } \\
\text { ZINGIBERACEAE } \\
\text { RA } 142\end{array}$ & Kachur & $\mathrm{H}$ & Whole plant & $\begin{array}{l}\text { Used to treat backbone pain, headache, stomach problem and urinary } \\
\text { disorder. }\end{array}$ \\
\hline 48. & $\begin{array}{l}\text { Curcuma aromatica Salisb. } \\
\text { ZINGIBERACEAE } \\
\text { RA } 56\end{array}$ & Hardi (M) & $\mathrm{H}$ & Rhizome & Used to cure pinash, gastritis and heart trouble. \\
\hline 49. & $\begin{array}{l}\text { Cuscuta reflexa } \text { Roxb. } \\
\text { CUSCUTACEAE } \\
\text { RA } 53\end{array}$ & Ranilata (M) & $\mathrm{C}$ & Whole plant & $\begin{array}{l}\text { Juice of the plant is given with crushed garlic to the cattle in case of } \\
\text { indigestion. Powder of the whole plant is used externally to cure } \\
\text { dandruff, scabies. Also used to cure jaundice. }\end{array}$ \\
\hline 50. & $\begin{array}{l}\text { Cymbopogon pendulus (Nees ex } \\
\text { Steud.) W. Watson } \\
\text { POACEAE } \\
\text { RA } 140\end{array}$ & Pirre & $\mathrm{H}$ & Whole plant & $\begin{array}{l}\text { Juice of the plant is given with crushed garlic to the cattle in case of } \\
\text { indigestion. Powder of the whole plant is used externally to cure } \\
\text { dandruff, scabies. Also used to cure jaundice. }\end{array}$ \\
\hline
\end{tabular}




\begin{tabular}{|c|c|c|c|c|c|}
\hline SNo. & $\begin{array}{l}\text { Plant species, Family and } \\
\text { Voucher number }\end{array}$ & Local name & $\begin{array}{l}\text { Life } \\
\text { form }\end{array}$ & Parts used & Uses \\
\hline 51. & $\begin{array}{l}\text { Cynoglossum zeylanicum } \\
\text { (Vahl ex Horhem) Thunb. ex } \\
\text { Lehm. } \\
\text { BORAGINACEAE } \\
\text { RA } 99\end{array}$ & Kanike kuro (M) & $\mathrm{H}$ & Flower & The paste of flower is applied to cure boils. \\
\hline 52. & $\begin{array}{l}\text { Cynodon dactylon (L.) Pers. } \\
\text { POACEAE } \\
\text { RA } 172\end{array}$ & Dubo & $\mathrm{H}$ & Leaf & $\begin{array}{l}\text { Crushed young leaf is eaten to improve defects of eye, stomach wash, } \\
\text { indigestion, excessive bleeding during menstruation, gastritis. }\end{array}$ \\
\hline 53. & $\begin{array}{l}\text { Cyperus rotundus } \mathrm{L} \text {. } \\
\text { CYPERACEAE } \\
\text { RA } 71\end{array}$ & Mothe & $\mathrm{H}$ & Leaf, Root & Used to treat indigestion, diarrhoea, vomiting, cough, bronchitis, fever. \\
\hline 54. & $\begin{array}{l}\text { Daphne papyracea Wall. ex } \\
\text { Steud. } \\
\text { THYMELIACEAE } \\
\text { RA } 195\end{array}$ & Seto baruwa & S & Seed and Root & $\begin{array}{l}\text { Seeds are anthelmintic. Root bark is crushed to make decoction and is } \\
\text { taken for curing digestive troubles. }\end{array}$ \\
\hline 55. & $\begin{array}{l}\text { Datura stramonium } \mathrm{L} \text {. } \\
\text { SOLANACEAE } \\
\text { RA } 52\end{array}$ & Dhaturo & $\mathrm{S}$ & $\begin{array}{l}\text { Flower, seed and } \\
\text { leaf }\end{array}$ & Used to treat toothache, bronchitis, asthma and insomnia (sleepiness). \\
\hline 56. & $\begin{array}{l}\text { Desmostachya bipinnata } \mathrm{L} \text {. } \\
\text { POACEAE } \\
\text { RA } 23\end{array}$ & Kush & $\mathrm{H}$ & Root & $\begin{array}{l}\text { Root paste is applied to treat toothache while juice is given in case of } \\
\text { stomach disorder. }\end{array}$ \\
\hline 57. & $\begin{array}{l}\text { Dichroa febrifuga Lour. } \\
\text { HYDRANGEACEAE } \\
\text { RA } 169\end{array}$ & Chhapo & $\mathrm{S}$ & Fruit & $\begin{array}{l}\text { Paste of fruit is mixed with powder of Curcuma which is taken daily to } \\
\text { cure gastritis. }\end{array}$ \\
\hline 58. & $\begin{array}{l}\text { Dioscorea bulbifera } \text { L. } \\
\text { DIOSCOREACEAE } \\
\text { RA } 161\end{array}$ & Lakwa (M) & $\mathrm{C}$ & Bulbil & Boiled bulbils are used to cure stomach pain, gastritis, round worm. \\
\hline 59. & $\begin{array}{l}\text { Dioscorea deltoidea Wall .ex } \\
\text { Griseb } \\
\text { DIOSCOREACEAE } \\
\text { RA } 128\end{array}$ & Bannamya (M) & $\mathrm{C}$ & Root & Paste of Tuber is used to kill louse. \\
\hline 60. & $\begin{array}{l}\text { Dioscorea pentaphylla } \mathrm{L} \text {. } \\
\text { DIOSCOREACEAE } \\
\text { RA } 136\end{array}$ & Bantarul & $\mathrm{C}$ & Bulbil/Tuber & $\begin{array}{l}\text { Boiled bulbils are used to cure back bone pain and Tuber is used as } \\
\text { vegetable. }\end{array}$ \\
\hline 61. & $\begin{array}{l}\text { Diploknema butyracea (Roxb.) } \\
\text { H. J. Lam } \\
\text { SAPOTACEAE } \\
\text { RA } 72\end{array}$ & Aakhen (M) & $\mathrm{T}$ & Seed & $\begin{array}{l}\text { Oil extracted from seed is used for massage to get relief from muscles } \\
\text { pain, ruptured skin of foot and hand. }\end{array}$ \\
\hline 62. & $\begin{array}{l}\text { Drymaria diandra } \text { Blume } \\
\text { CARYOPHYLLACEAE } \\
\text { RA } 55\end{array}$ & Naplupya (M) & $\mathrm{H}$ & Leaf & $\begin{array}{l}\text { Leaf Juice is taken during indigestion. Leaves are smouldered over fire } \\
\text { and inhaled through nose in case of headache. Also cure hotness of body } \\
\text { sinusitis. }\end{array}$ \\
\hline 63. & $\begin{array}{l}\text { Duchesnea indica (Andrews) } \\
\text { Focke } \\
\text { ROSACEAE } \\
\text { RA } 64\end{array}$ & $\begin{array}{l}\text { Kauwa kaphal } \\
\text { (M) }\end{array}$ & $\mathrm{H}$ & Whole plant & $\begin{array}{l}\text { Plant paste mixed with paste of Centella asiatica and applied on } \\
\text { forehead to get relief from headache. }\end{array}$ \\
\hline 64. & $\begin{array}{l}\text { Entada phasioloides (L.) Merr. } \\
\text { LEGUMIONOSAE } \\
\text { RA } 118\end{array}$ & Lek pangra $(\mathrm{M})$ & $\mathrm{T}$ & Fruit & Used to cure arthritis, swelling due to coldness. Also used to kill fishes \\
\hline 65. & $\begin{array}{l}\text { Equisetum debile Roxb. ex } \\
\text { Vaucher } \\
\text { EQUISETACEAE } \\
\text { RA } 153\end{array}$ & Kurkure (M) & $\mathrm{H}$ & Whole plant & $\begin{array}{l}\text { Used for balancing hotness and coldness (sardigarmi milaun) in the } \\
\text { body. }\end{array}$ \\
\hline 66. & $\begin{array}{l}\text { Erythrina stricta } \text { Roxb. } \\
\text { LEGUMINOSAE } \\
\text { RA } 83\end{array}$ & Mohorje (M) & $\mathrm{T}$ & Bark & Used to cure hotness of body and constipation. \\
\hline 67. & $\begin{array}{l}\text { Eulaliopsis binnata }(\text { Retz. } \text { C.E. } \\
\text { Hubb. } \\
\text { POAECAE } \\
\text { RA164 }\end{array}$ & Bankasi (M) & $\mathrm{H}$ & Whole plant & Leaf or root juice is given in case of urinary trouble. \\
\hline 68. & $\begin{array}{l}\text { Eupatorium adenophorum } \\
\text { Spreng. } \\
\text { COMPOSITAE } \\
\text { RA } 22\end{array}$ & Banmara (M) & $\mathrm{H}$ & Leaf & Paste of leaf is applied to cure cut wounds. \\
\hline 69. & $\begin{array}{l}\text { Euphorbia royleana } \text { Boiss. } \\
\text { EUPHORBIACEAE } \\
\text { RA } 104\end{array}$ & Sijha (M) & S & Bark, Leaf & $\begin{array}{l}\text { Leaf juice is used to cure ringworm. Latex of bark is used to cure } \\
\text { tetanus. }\end{array}$ \\
\hline 70. & $\begin{array}{l}\text { Ficus benghalensis } \mathrm{L} \text {. } \\
\text { MORACEAE } \\
\text { RA } 120\end{array}$ & Bar & $\mathrm{T}$ & Leaf, Bark & $\begin{array}{l}\text { Tender leaves are used to cure cholera or dysentery, bark juice is useful } \\
\text { in diabetes, latex of leaf or bark is used to treat ulcer. }\end{array}$ \\
\hline 71. & $\begin{array}{l}\text { Ficus religiosa } \mathrm{L} \text {. } \\
\text { MORACEAE } \\
\text { RA } 07\end{array}$ & Pipar (M) & $\mathrm{T}$ & Bark & Bark juice is used to cure cut wounds. \\
\hline 72. & $\begin{array}{l}\text { Girardiana diversifolia (Link) } \\
\text { Fris } \\
\text { URTICACEAE } \\
\text { RA 95 }\end{array}$ & $\begin{array}{l}\text { Chalne sisnoo } \\
\text { (M) }\end{array}$ & $\mathrm{H}$ & Leaf & Leaf juice is given to cure anaemia, fever, headache, menstrual disorder. \\
\hline 73. & $\begin{array}{l}\text { Gaultheria fragrantissima Wall. } \\
\text { ERICACEAE } \\
\text { RA } 175\end{array}$ & Dhasingre & S & Leaf, Fruit & $\begin{array}{l}\text { Paste of leaf is used to cure sprain and paste of fruit is used to treat } \\
\text { stomach worm. }\end{array}$ \\
\hline 74. & $\begin{array}{l}\text { Imperata cylindrica }(\text { L.) Palisot } \\
\text { POACEAE } \\
\text { RA } 174\end{array}$ & Siuri (M) & $\mathrm{H}$ & Rhizome & Used to treat gastritis, dysentery. Rhizome powder is anthelmintic. \\
\hline
\end{tabular}




\begin{tabular}{|c|c|c|c|c|c|}
\hline SNo. & $\begin{array}{l}\text { Plant species, Family and } \\
\text { Voucher number }\end{array}$ & Local name & $\begin{array}{c}\text { Life } \\
\text { form }\end{array}$ & Parts used & Uses \\
\hline 75. & $\begin{array}{l}\text { Inula cappa (Buch.-Ham. ex D. } \\
\text { Don) DC. } \\
\text { COMPOSITAE } \\
\text { RA } 115\end{array}$ & $\begin{array}{l}\text { Bachhadanga } \\
\text { (M) }\end{array}$ & S & Root & Root juice is used to treat fever, headache, giddiness and tonsillitis. \\
\hline 76. & $\begin{array}{l}\text { Jatropha curcas L. } \\
\text { EUPHORBIACEAE } \\
\text { RA 51 }\end{array}$ & Rathyn (M) & S & Stem & Twigs are used as toothbrush to cure discharge of blood from the gums. \\
\hline 77. & $\begin{array}{l}\text { Juglans regia } \mathrm{L} \text {. } \\
\text { JUGLANDACEAE } \\
\text { RA } 11\end{array}$ & Okhar & $\mathrm{T}$ & Fruit, Bark & Used to treat skin diseases. Bark juice is anthelmintic. \\
\hline 78. & $\begin{array}{l}\text { Justicia adhatoda L } \\
\text { ACANTHACEAE } \\
\text { RA } 05\end{array}$ & Machham (M) & S & Leaf & $\begin{array}{l}\text { A decoction of leaves is taken to cure fever, cough ( } k \text { hoki, dam), } \\
\text { scabies, joint pain, burning sensation of eye. Also used as pesticides. }\end{array}$ \\
\hline 79. & $\begin{array}{l}\text { Kalanchoe pinnata } \text { Pers } \\
\text { CRASSULACEAE } \\
\text { RA } 127\end{array}$ & Ajambari jhar & $\mathrm{H}$ & Leaf & Paste of leaf is applied to cure wound and blisters (khatira). \\
\hline 80. & $\begin{array}{l}\text { Lantana camera } \text { L. } \\
\text { VERBENACEAE } \\
\text { RA } 62\end{array}$ & Banmara & S & Leaf & Paste of leaf is applied to cure cut wounds. \\
\hline 81. & $\begin{array}{l}\text { Leucas lanata Benth. } \\
\text { LABIATAE } \\
\text { RA } 112\end{array}$ & Gante jhar (M) & $\mathrm{H}$ & Whole plant & Plant juice is used to cure jaundice. \\
\hline 82. & $\begin{array}{l}\text { Lilium wallichiamum Schultes \& } \\
\text { Schultes. f. } \\
\text { LILIACEAE } \\
\text { RA } 61\end{array}$ & Hadelasun & $\mathrm{H}$ & Bulb & Used to cure joint pain, backbone problem and kidney problem. \\
\hline 83. & $\begin{array}{l}\text { Lindera neesiana (Wall.ex Nees) } \\
\text { Kurz } \\
\text { LAURACEAE } \\
\text { RA } 33\end{array}$ & Siltimur & $\mathrm{T}$ & Seed & $\begin{array}{l}\text { A decoction of seed is taken to cure gastritis and diarrhoea. Also used as } \\
\text { antidote of poison. }\end{array}$ \\
\hline 84. & $\begin{array}{l}\text { Lobelia pyramidalis Wall. } \\
\text { CAMPANULACEAE } \\
\text { RA } 107\end{array}$ & Eklebir & $\mathrm{H}$ & $\begin{array}{l}\text { Flower, leaf and } \\
\text { bark }\end{array}$ & $\begin{array}{l}\text { Used to treat asthma, cough, bronchitis, fever, jaundice, urinary problem } \\
\text { and tonic. }\end{array}$ \\
\hline 85. & $\begin{array}{l}\text { Lycopodium clavatum L. } \\
\text { LYCOPODIACEAE } \\
\text { RA } 59\end{array}$ & Nagbeli laharo & $\mathrm{C}$ & Cone & Dust of spores of the cone is applied in old infected wounds, sores. \\
\hline 86. & $\begin{array}{l}\text { Lyonia ovalifolia (Wall.) Drude } \\
\text { ERICACEAE } \\
\text { RA } 26\end{array}$ & Pharsing $(\mathrm{M})$ & S & Leaf, Bark & $\begin{array}{l}\text { Juice of young leaf is used to cure scabies and ringworm. Bark juice is } \\
\text { anthelmintic. }\end{array}$ \\
\hline 87. & $\begin{array}{l}\text { Maesia chisia } \text { Buch.-Ham. ex D. } \\
\text { Don } \\
\text { MYRSINACE } \\
\text { RA } 21\end{array}$ & Bilouni & $\mathrm{T}$ & $\begin{array}{l}\text { Stem, Leaf \& } \\
\text { Fruit }\end{array}$ & $\begin{array}{l}\text { Bark juice anthelmintic, used to treat ringworm and paste of ripe fruit is } \\
\text { applied to treat scabies. Bark \& leaf juice are also used as fish poison. }\end{array}$ \\
\hline 88. & $\begin{array}{l}\text { Mahonia nepaulensis DC. } \\
\text { BERBERIDACEAE } \\
\text { RA } 69\end{array}$ & Jamane mandro & S & Fruit, Bark & $\begin{array}{l}\text { Ripe fruits are used to treat dysentery, urinary problem and skin } \\
\text { diseases. Bark juice is used as an eye drop for eye inflammation. }\end{array}$ \\
\hline 89. & $\begin{array}{l}\text { Mallotus philippensis (Lam.) } \\
\text { Muller.- Arg. } \\
\text { EUPHORBIACEAE } \\
\text { RA } 191\end{array}$ & Rohini (M) & $\mathrm{T}$ & Fruit, Root & $\begin{array}{l}\text { Used to cure scabies, asthma, ringworm, dandruff. Root juice is used to } \\
\text { cure gastritis. }\end{array}$ \\
\hline 90. & $\begin{array}{l}\text { Mangifera indica } \mathrm{L} \text {. } \\
\text { ANACARDIACEAE } \\
\text { RA } 08\end{array}$ & Satak (M) & $\mathrm{T}$ & $\begin{array}{l}\text { Leaf, bark and } \\
\text { fruit }\end{array}$ & $\begin{array}{l}\text { Used to cure dysentery, stomach problem, scabies and other skin } \\
\text { diseases. Ripe fruits constitute a rich source of vitamin A. }\end{array}$ \\
\hline 91. & $\begin{array}{l}\text { Melia azedarach L. } \\
\text { MELIACEAE } \\
\text { RA } 60\end{array}$ & Bakaina (M) & $\mathrm{T}$ & Bark & Bark juice is anthelmintic. \\
\hline 92. & $\begin{array}{l}\text { Mentha spicata } \mathrm{L} \text {. } \\
\text { LABIATAE } \\
\text { RA } 106\end{array}$ & Bamarisar (M) & $\mathrm{H}$ & Leaf & $\begin{array}{l}\text { Used to cure gastritis, dysentery and diarrhoea. Leaf juice and ginger is } \\
\text { taken during vomiting. }\end{array}$ \\
\hline 93. & $\begin{array}{l}\text { Mentha arvensis } \mathrm{L} \text {. } \\
\text { LABIATAE } \\
\text { RA } 163\end{array}$ & Patuna (M) & $\mathrm{H}$ & Leaf & Cure hotness of body and headache. \\
\hline 94. & $\begin{array}{l}\text { Michelia champaca } \mathrm{L} \text {. } \\
\text { MAGNOLIACEAE } \\
\text { RA } 25\end{array}$ & Chanp & $\mathrm{T}$ & Bark, Fruit & $\begin{array}{l}\text { Bark juice is used to cure infected wound, scabies, gastritis and fruit is } \\
\text { useful to cure fever, cholera and kidney problem. }\end{array}$ \\
\hline 95. & $\begin{array}{l}\text { Mucuna pruriens (L.) DC. } \\
\text { LEGUMINOSAE } \\
\text { RA } 101\end{array}$ & Kaucho & $\mathrm{C}$ & Seed & Used to treat fever, menstrual disorder and sterility. \\
\hline 96. & $\begin{array}{l}\text { Myrica esculenta } \text { Buch.-Ham. ex } \\
\text { D. Don } \\
\text { MYRICACEAE } \\
\text { RA } 73\end{array}$ & Hande kaphal & $\mathrm{T}$ & Bark & $\begin{array}{l}\text { Bark juice is used to cure fever, asthma, indigestion, toothache and } \\
\text { measles. Fruits are edible. }\end{array}$ \\
\hline 97. & $\begin{array}{l}\text { Nephrolopsis cordifolia }(\mathrm{L} .) \mathrm{K} . \\
\text { PresI } \\
\text { DRYOPTERIDACEAE } \\
\text { RA } 31\end{array}$ & Sanghrap (M) & $\mathrm{H}$ & Rhizome & $\begin{array}{l}\text { Cure hotness of body and headache. Rhizome is also used to quench the } \\
\text { thirst. }\end{array}$ \\
\hline 98. & $\begin{array}{l}\text { Ocimum tenuiflorum } \mathrm{L} \text {. } \\
\text { LABIATAE } \\
\text { RA } 111\end{array}$ & Ban tulasa $(\mathrm{M})$ & $\mathrm{H}$ & Whole plant & $\begin{array}{l}\text { Used to treat cough, cold, asthma, fever, burning sensation in eye, } \\
\text { earache (kan dukhema, pakema), high blood pressure and gastritis. }\end{array}$ \\
\hline 99. & $\begin{array}{l}\text { Oroxylum indicum (L.) Kurtz } \\
\text { BIGNONIACEAE } \\
\text { RA } 199\end{array}$ & Saunetata $(\mathrm{M})$ & $\mathrm{T}$ & Seed & Used to cure typhoid. \\
\hline
\end{tabular}




\begin{tabular}{|c|c|c|c|c|c|}
\hline SNo. & $\begin{array}{l}\text { Plant species, Family and } \\
\text { Voucher number }\end{array}$ & Local name & $\begin{array}{l}\text { Life } \\
\text { form }\end{array}$ & Parts used & Uses \\
\hline 100. & $\begin{array}{l}\text { Osyris wightiana Wall. } \\
\text { SANTALACEAE } \\
\text { RA } 119\end{array}$ & Syarus (M) & S & Leaf & $\begin{array}{l}\text { Leaf paste is applied and bandaged by cloth from outside in case of bone } \\
\text { fracture and wound. Also used as pesticides. Young leaves are } \\
\text { poisonous for goat. }\end{array}$ \\
\hline 101. & $\begin{array}{l}\text { Oxalis corniculata } \mathrm{L} \text {. } \\
\text { OXALIDACEAE } \\
\text { RA } 162\end{array}$ & Jhyamruk (M) & $\mathrm{H}$ & Whole plant & $\begin{array}{l}\text { Plant juice is used to cure conjunctivitis, toothache, earache and } \\
\text { stomach-ache. Also cure hotness of body. }\end{array}$ \\
\hline 102. & $\begin{array}{l}\text { Oxalis latifolia } \text { Humb. } \\
\text { OXALIDACEAE } \\
\text { RA } 48\end{array}$ & Amilijhar & $\mathrm{H}$ & Whole plant & Used to cure dysentery, cholera and gastritis. \\
\hline 103. & $\begin{array}{l}\text { Paris polyphylla } \mathrm{Sm} \text {. } \\
\text { LILIACEAE } \\
\text { RA } 103\end{array}$ & Satuwa & $\mathrm{H}$ & rhizome & $\begin{array}{l}\text { Used to cure cut wounds, blisters, burns, headache, fever and as antidote } \\
\text { of poison (mainly to neutralize poison when the livestock feed on } \\
\text { poisonous herbs). }\end{array}$ \\
\hline 104. & $\begin{array}{l}\text { Parmelia nepalensis Tayl. } \\
\text { PARMELIACEAE } \\
\text { RA } 102\end{array}$ & Jhyau & $\mathrm{H}$ & All parts & Used to cure disease of gum, throat scabies, piles and leprosy. \\
\hline 105. & $\begin{array}{l}\text { Persea odorattisima } \text { (Nees) } \\
\text { Koesterm } \\
\text { LAURACEAE } \\
\text { RA } 123\end{array}$ & Yatlak (M) & $\mathrm{T}$ & Bark & $\begin{array}{l}\text { Bark paste is applied and bandage by cloth from outside in case of bone } \\
\text { fracture. }\end{array}$ \\
\hline 106. & $\begin{array}{l}\text { Phyllanthus emblica } \mathrm{L} \text {. } \\
\text { EUPHORBIACEAE } \\
\text { RA } 50\end{array}$ & Ghormet (M) & $\mathrm{T}$ & $\begin{array}{l}\text { Seed, fresh fruit } \\
\text { and bark }\end{array}$ & $\begin{array}{l}\text { One of the constituents of triphala which is used to treat gastritis, for } \\
\text { cooling, diuretic and laxative, source of vitamin C. Bark juice is used to } \\
\text { treat fever and dysentery. The infusion of seeds is a useful eye-wash in } \\
\text { ophthalmic diseases. }\end{array}$ \\
\hline 107. & $\begin{array}{l}\text { Phyllanthus parvifolius (Buch.- } \\
\text { Ham. ex D.Don } \\
\text { EUPHORBIACEAE } \\
\text { RA } 43\end{array}$ & Khabreto (M) & S & Leaf & Leaf paste is used to cure sprain (sarke-markema) and bone fracture. \\
\hline 108. & $\begin{array}{l}\text { Piper longum } \mathrm{L} \text {. } \\
\text { PIPERACEAE } \\
\text { RA } 193\end{array}$ & Pipala & $\mathrm{C}$ & Fruit & Used to cure cough (khoki, dam), leprosy and indigestion. \\
\hline 109. & $\begin{array}{l}\text { Piper chaba Hunter } \\
\text { PIPERACEAE } \\
\text { RA } 194\end{array}$ & Chabo & S & Fruit, Leaf & Used to cure mouth wound and abdominal disorder. \\
\hline 110. & $\begin{array}{l}\text { Pimus roxburghii Sargent } \\
\text { PINACEAE } \\
\text { RA } 04\end{array}$ & Arghii (M) & $\mathrm{T}$ & Bark & $\begin{array}{l}\text { Resin extracted from the bark is applied around boils to draw output. } \\
\text { Resin is also used as stimulant, stomachic and diuretic. }\end{array}$ \\
\hline 111. & $\begin{array}{l}\text { Plantago major } \mathrm{L} \text {. } \\
\text { PLANTAGINACEAE } \\
\text { RA } 06\end{array}$ & Isabagol & $\mathrm{H}$ & $\begin{array}{l}\text { Seed and seed } \\
\text { husk }\end{array}$ & $\begin{array}{l}\text { Used to treat fever, diarrhoea dysentery, laxative, demulcent, } \\
\text { expectorant, diuretic. }\end{array}$ \\
\hline 112. & $\begin{array}{l}\text { Pogostemon benghalensis (Burm. } \\
\text { f.) Kuntze } \\
\text { LABIATAE } \\
\text { RA } 118\end{array}$ & Makaisar (M) & $\mathrm{S}$ & Leaf & Used to cure common cold, cough and fever. \\
\hline 113. & $\begin{array}{l}\text { Potentilla fulgens Wall.ex. Hook } \\
\text { ROSACEAE } \\
\text { RA } 146\end{array}$ & Bajradanti & $\mathrm{H}$ & Root, Leaf & $\begin{array}{l}\text { Root juice is used to treat toothache, bleeding from the gum and leaf } \\
\text { juice in dysentery. }\end{array}$ \\
\hline 114. & $\begin{array}{l}\text { Prumus cerasoides D. Don } \\
\text { ROSACEAE } \\
\text { RA } 129\end{array}$ & Phalamsing (M) & $\mathrm{T}$ & Bark & $\begin{array}{l}\text { Used to cure gastritis, sprain (sarke-markema). Bark juice is } \\
\text { anthelmintic. }\end{array}$ \\
\hline 115. & $\begin{array}{l}\text { Pisidium gujava } \mathrm{L} \text {. } \\
\text { MYRTACEAE } \\
\text { RA } 03\end{array}$ & Amba & $\mathrm{T}$ & Leaf, Fruit & $\begin{array}{l}\text { Extract of leaf is taken during vomiting. Boiled fruit is eaten during } \\
\text { indigestion. }\end{array}$ \\
\hline 116. & $\begin{array}{l}\text { Pteris biaurita } \mathrm{L} \text {. } \\
\text { PTERIDACEAE } \\
\text { RA } 126\end{array}$ & Sanghrap (M) & $\mathrm{H}$ & Leaf & Used to cure cut wounds. \\
\hline 117. & $\begin{array}{l}\text { Pyrossia sp. } \\
\text { POLYPODIACEAE } \\
\text { RA } 176\end{array}$ & Unyu & $\mathrm{H}$ & Root & Used to cure acute rheumatism and joint problem. \\
\hline 118. & $\begin{array}{l}\text { Pyrus pashia Buch.-Ham. ex } \\
\text { D.Don } \\
\text { ROSACEAE } \\
\text { RA } 12\end{array}$ & Ghorpal (M) & $\mathrm{T}$ & Fruit & Used to cure diarrhoea, indigestion. \\
\hline 119. & $\begin{array}{l}\text { Quercus semecarpifolia } \mathrm{Sm} \text {. } \\
\text { FAGACEAE } \\
\text { RA } 131\end{array}$ & Khasru (M) & $\mathrm{T}$ & Bark & Used to treat backbone pain. Also used for cattle illness. \\
\hline 120. & $\begin{array}{l}\text { Ramalina } \text { sp. } \\
\text { USNEACEAE } \\
\text { RA } 132\end{array}$ & Jhyau & $\mathrm{H}$ & Whole plant & Antiseptic, burns and wounds, epilepsy, ointment and antibiotic. \\
\hline 121. & $\begin{array}{l}\text { Reimwardtia indica Dumort } \\
\text { LINACEAE } \\
\text { RA } 13\end{array}$ & Pyauli & s & Flower & $\begin{array}{l}\text { Used to cure gastritis, indigestion balancing hotness and coldness in the } \\
\text { body (sardi garmi milaun). }\end{array}$ \\
\hline 122. & $\begin{array}{l}\text { Rhododendron arboreum } \mathrm{Sm} \text {. } \\
\text { ERICACEAE } \\
\text { RA } 133\end{array}$ & Pataksar (M) & $\mathrm{T}$ & Fruit & Used to cure stomach disease, indigestion, dysentery, gastritis and tonic. \\
\hline 123. & $\begin{array}{l}\text { Rhus javanica } \mathrm{L} \text {. } \\
\text { ANACARDIACEAE } \\
\text { RA } 177\end{array}$ & Muruk (M) & $\mathrm{T}$ & Fruit & Powder of fruit is taken with curd to cure diarrhoea and dysentery. \\
\hline 124. & $\begin{array}{l}\text { Rhus wallichi Hook.f. } \\
\text { ANACARDIACEAE } \\
\text { RA } 116\end{array}$ & Jhyano & $\mathrm{H}$ & Whole plant & Used to cure stomach problem. \\
\hline 125. & $\begin{array}{l}\text { Rubia manjith Roxb, ex Fleming } \\
\text { RUBIACEAE } \\
\text { RA } 42\end{array}$ & Gijanbhik (M) & $\mathrm{C}$ & Whole plant & $\begin{array}{l}\text { Used to cure jaundice, joint pain, bronchial problem, appetizer. Plant } \\
\text { juice is anthelmintic. }\end{array}$ \\
\hline
\end{tabular}




\begin{tabular}{|c|c|c|c|c|c|}
\hline SNo. & $\begin{array}{l}\text { Plant species, Family and } \\
\text { Voucher number }\end{array}$ & Local name & $\begin{array}{l}\text { Life } \\
\text { form }\end{array}$ & Parts used & Uses \\
\hline 126. & $\begin{array}{l}\text { Rubus elipticus } \mathrm{Sm} . \\
\text { ROSACEAE } \\
\text { RA } 14\end{array}$ & Chigausi (M) & S & $\begin{array}{l}\text { Fruit Stem and } \\
\text { root }\end{array}$ & $\begin{array}{l}\text { Ripe fruits are eaten raw to cure coldness in the body. Root juice is } \\
\text { taken to cure pneumonia, fever, stomach-ache. Inner stem is chewed to } \\
\text { cure tonsillitis. }\end{array}$ \\
\hline 127. & $\begin{array}{l}\text { Rubus paniculatus } \mathrm{Sm} \text {. } \\
\text { ROSACEAE } \\
\text { RA } 24\end{array}$ & Chigausi (M) & $\mathrm{S}$ & Root, stem & $\begin{array}{l}\text { Decoction of root and stem is used to cure pneumonia usually among } \\
\text { children. }\end{array}$ \\
\hline 128. & $\begin{array}{l}\text { Rumex nepalensis Spreng. } \\
\text { POLYGONACEAE } \\
\text { RA } 02\end{array}$ & Halhale & $\mathrm{H}$ & Rhizome & Paste of rhizome is applied to cure swelling. \\
\hline 129. & $\begin{array}{l}\text { Schima wallichii (DC.) Korth. } \\
\text { THEACEAE } \\
\text { RA } 178\end{array}$ & Ghyansing (M) & $\mathrm{T}$ & Fruit, Bark & $\begin{array}{l}\text { Fruit paste is applied as antidote against scorpion sting Bark juice is } \\
\text { applied on cut wounds to stop bleeding. Crushed bark is given with } \\
\text { grain to the cattle against liver flukes and intestinal worms. }\end{array}$ \\
\hline 130. & $\begin{array}{l}\text { Scuttelaria repens } \text { Buch.-Ham. } \\
\text { ex D. Don } \\
\text { LABIATAE } \\
\text { RA } 130\end{array}$ & Pepema jhar (M) & $\mathrm{H}$ & Whole plant & Plant juice is used to cure tetanus. \\
\hline 131. & $\begin{array}{l}\text { Selinum wallichiamum (DC.) } \\
\text { Reizanda and Saxena } \\
\text { UMBELLIFERAE } \\
\text { RA } 134\end{array}$ & Bhutkesh & $\mathrm{H}$ & Root & $\begin{array}{l}\text { Decoction of root is used to cure rheumatism. Root paste is used to get } \\
\text { relief from body pain and fever. }\end{array}$ \\
\hline 132. & $\begin{array}{l}\text { Semicarpus anacardium } \mathrm{L} . \mathrm{f} \text {. } \\
\text { ANACARDIACEAE } \\
\text { RA } 50\end{array}$ & Bhalayo & $\mathrm{T}$ & Fruit & Used to cure dysentery, asthma and acute rheumatism. \\
\hline 133. & $\begin{array}{l}\text { Shorea robusta Gaertn. } \\
\text { DIPTEROCARPACEAE } \\
\text { RA } 194\end{array}$ & Phoksing (M) & $\mathrm{T}$ & Bark & $\begin{array}{l}\text { The powdered resin extracted from bark is taken with curd during } \\
\text { dysentery. }\end{array}$ \\
\hline 134. & $\begin{array}{l}\text { Smilax aspera L. LILIACEAE } \\
\text { RA } 01\end{array}$ & Narbhok (M) & $\mathrm{C}$ & Root & Root juice is taken to cure stomach-ache, bowels and vomiting problem. \\
\hline 135. & $\begin{array}{l}\text { Solanum virginianum } \mathrm{L} \text {. } \\
\text { SOLANACEAE } \\
\text { RA } 179\end{array}$ & Kanthagiri (M) & $\mathrm{H}$ & Fruit, Seed & $\begin{array}{l}\text { Roasted few seeds are kept on the infected teeth during toothache. } \\
\text { Powder of fruit is used to cure epilepsy. }\end{array}$ \\
\hline 136. & $\begin{array}{l}\text { Solanum anguivi Lam. } \\
\text { SOLANACEAE } \\
\text { RA } 136\end{array}$ & Bihin & $\mathrm{S}$ & Fruit & $\begin{array}{l}\text { During headache caused by cough and cold, fruit is squeezed and the } \\
\text { juice along with seeds is rubbed on forehead. }\end{array}$ \\
\hline 137. & $\begin{array}{l}\text { Sapilanthes calva } \text { DC. } \\
\text { COMPOSITAE } \\
\text { RA } 39\end{array}$ & Ban maratti $(\mathrm{M})$ & $\mathrm{H}$ & Flower & $\begin{array}{l}\text { Decoction of flower is taken to cure cough and cold. A single flower } \\
\text { head is kept on the infected teeth during toothache. }\end{array}$ \\
\hline 138. & $\begin{array}{l}\text { Spindus mukorossi Gaertn. } \\
\text { SAPINDACEAE } \\
\text { RA } 87\end{array}$ & Jharlyang (M) & $\mathrm{T}$ & Fruit & $\begin{array}{l}\text { Fruit is used to cure epilepsy, asthma, expectorant. Pulp of fruit can be } \\
\text { used as substitute of washing soap. Also used in fish poisoning or } \\
\text { fishing. }\end{array}$ \\
\hline 139. & $\begin{array}{l}\text { Swertia ciliata (D. Don ex G. } \\
\text { Don) B. L. Burtt } \\
\text { GENTINACEAE RA } 08\end{array}$ & Lekhtite (M) & $\mathrm{H}$ & Whole plant & $\begin{array}{l}\text { Decoction of plant is mixed with curd and given to cure diarrhoea. Plant } \\
\text { juice is used to cure typhoid. }\end{array}$ \\
\hline 140. & $\begin{array}{l}\text { Swertia nervosa (G. Don) CB } \\
\text { Clarke } \\
\text { GENTIANACEAE RA } 54\end{array}$ & Lehktite (M) & $\mathrm{H}$ & Whole plant & Plant juice is taken during abdominal disorder. \\
\hline 141. & $\begin{array}{l}\text { Syzygium cumini (L.) Skeels } \\
\text { MYRTACEAE } \\
\text { RA } 99\end{array}$ & Pharet (M) & $\mathrm{T}$ & Bark, Fruit & $\begin{array}{l}\text { Bark juice is given during diarrhoea and dysentery. Ripe fruits are } \\
\text { edible. }\end{array}$ \\
\hline 142. & $\begin{array}{l}\text { Terminalia chebula } \text { Retz } \\
\text { COMBRETACEAE } \\
\text { RA } 126\end{array}$ & Bor $(\mathrm{M})$ & $\mathrm{T}$ & Fruit, Bark & $\begin{array}{l}\text { Fruit is one of the constituent of triphala that is used for constipation, } \\
\text { stomach pain, cough. Bark juice is useful for jaundice, bronchial } \\
\text { problem, stone, blood pressure. }\end{array}$ \\
\hline 143. & $\begin{array}{l}\text { Terminalia bellirica (Gaertn.) } \\
\text { Roxb. } \\
\text { COMBRETACEAE RA } 194\end{array}$ & Thuksing (M) & $\mathrm{T}$ & Fruit & $\begin{array}{l}\text { Used to remedy in cough, fever, piles, leprosy, appetizer, one of the } \\
\text { constituent of triphala. }\end{array}$ \\
\hline 144. & $\begin{array}{l}\text { Themeda triandra Forssk. } \\
\text { POACEAE } \\
\text { RA } 166\end{array}$ & Khar & $\mathrm{H}$ & Leaf & Leaf juice is useful for gastritis. \\
\hline 145. & $\begin{array}{l}\text { Thespesia lampas (Cav.) Dalzell } \\
\text { \& Gibson } \\
\text { MALVACEAE RA } 125\end{array}$ & Ban kapas & $\mathrm{S}$ & Stem, Root & Used to reduce joint pain, backbone pain and to make strong bone. \\
\hline 146. & $\begin{array}{l}\text { Thysanolaena maxima (Roxb.) } \\
\text { Kuntze } \\
\text { POACEAE RA } 58\end{array}$ & Badani $(M)$ & $\mathrm{H}$ & Root & Root juice is taken during stomach pain and for gastritis. \\
\hline 147. & $\begin{array}{l}\text { Tinospora cordifolia } \text { (Willd) } \\
\text { Miers } \\
\text { MENISPERMACEAE RA } 103\end{array}$ & Gurjegana (M) & $\mathrm{C}$ & Stem & $\begin{array}{l}\text { Used to cure asthma, cough, bronchitis fever, jaundice, urinary problem, } \\
\text { diabetes and tonic. }\end{array}$ \\
\hline 148. & $\begin{array}{l}\text { Trichilia connaroides (Wight \& } \\
\text { Arn.) Bentv. } \\
\text { MELIACEAE RA } 43\end{array}$ & Chhoyosar (M) & $\mathrm{T}$ & Fruit & Used to cure wound, scabies, ring worm and other skin disease. \\
\hline 149. & $\begin{array}{l}\text { Trichosanthes tricuspidata } \text { Lour. } \\
\text { CUCURBITACEAE } \\
\text { RA } 98\end{array}$ & Inddrayani $(\mathrm{M})$ & $\mathrm{C}$ & Root, Fruit & $\begin{array}{l}\text { Root juice is taken during abdominal pain. Root/fruit paste is applied to } \\
\text { cure boils. }\end{array}$ \\
\hline 150. & $\begin{array}{l}\text { Urtica dioica } \mathrm{L} \text {. } \\
\text { URTICACEAE } \\
\text { RA } 67\end{array}$ & Ghyo (M) & $\mathrm{H}$ & Leaf & $\begin{array}{l}\text { Regular intake of young shoots as vegetable provides relief from } \\
\text { diabetes, anaemia. Leaf paste is applied on the cuts and dog bite. }\end{array}$ \\
\hline 151. & $\begin{array}{l}\text { Valeriana jatamansii Tones } \\
\text { VALERIANACEAE } \\
\text { RA } 100\end{array}$ & Somai jhar (M) & $\mathrm{H}$ & Root/Stem & $\begin{array}{l}\text { Watery extract obtained by crushing stem is filtered and applied as eye } \\
\text { drop in case of conjunctivitis. Root juice is tonic which helps in post } \\
\text { delivery. }\end{array}$ \\
\hline 152. & $\begin{array}{l}\text { Viburmum erubescens Wall. } \\
\text { CAPRIFOLIACEAE } \\
\text { RA } 97\end{array}$ & $\begin{array}{l}\text { Guwatyotsing } \\
\text { (M) }\end{array}$ & $\mathrm{S}$ & Bark & Used to cure common cold and typhoid. \\
\hline
\end{tabular}




\begin{tabular}{|c|c|c|c|c|c|}
\hline SNo. & $\begin{array}{l}\text { Plant species, Family and } \\
\text { Voucher number }\end{array}$ & Local name & $\begin{array}{l}\text { Life } \\
\text { form }\end{array}$ & Parts used & Uses \\
\hline 153. & $\begin{array}{l}\text { Vitex negundo } \mathrm{L} . \\
\text { VALERIANACEAE } \\
\text { RA } 153\end{array}$ & Simali & S & Leaf & $\begin{array}{l}\text { Leaf paste is applied to cure blisters. Leaf juice is used to cure pinash, } \\
\text { cough and asthma. }\end{array}$ \\
\hline 154. & $\begin{array}{l}\text { Wikstroemia canescens Meisssn } \\
\text { THYMELIACEAE } \\
\text { RA } 70\end{array}$ & Dandapate (M) & S & Root & Root bark is crushed to make powder and is given during indigestion. \\
\hline 155. & $\begin{array}{l}\text { Woodfordia fruticosa } \text { (L.) Kurze } \\
\text { LYTHRACEAE } \\
\text { RA } 57\end{array}$ & Jharyak (M) & $\mathrm{S}$ & Leaf & $\begin{array}{l}\text { Used to reduce labour pain, to control bleeding on cut wounds, gastritis, } \\
\text { and dysentery and skin diseases. }\end{array}$ \\
\hline 156. & $\begin{array}{l}\text { Xeromphis spinosa } \text { (Thunb.) } \\
\text { Keay } \\
\text { RUBIACEAE } \\
\text { RA } 68\end{array}$ & Main kanda & S & Root & Root paste is applied on the forehead to get relief from headache. \\
\hline 157. & $\begin{array}{l}\text { Yongia japonica }(\mathrm{L} .) \text { DC. } \\
\text { COMPOSITAE } \\
\text { RA } 151\end{array}$ & Dulla jhar & $\mathrm{H}$ & Leaf & Leaf juice is taken during indigestion. \\
\hline 158. & $\begin{array}{l}\text { Zanthoxylum armatum DC. } \\
\text { RUTACEAE } \\
\text { RA } 165\end{array}$ & Timur & $\mathrm{T}$ & Fruit & $\begin{array}{l}\text { Fruit is chewed to cure toothache, fever, gastritis. Decoction of fruit } \\
\text { with salt and powdered turmeric is taken to treat cough and cold. }\end{array}$ \\
\hline 159. & $\begin{array}{l}\text { Zephyranthes cariata Herbert } \\
\text { AMARYLLIDACEAE } \\
\text { RA } 96\end{array}$ & Bhuichampa & $\mathrm{H}$ & Rhizome & Used to cure backbone pain, joint pain and bone fracture. \\
\hline 160. & $\begin{array}{l}\text { Zingiber cassumunar } \text { Roxb. } \\
\text { ZINGIBERACEAE } \\
\text { RA } 154\end{array}$ & Chhebok (M) & $\mathrm{H}$ & Root & Used to cure pinash, gastritis and heart problem \\
\hline 161. & $\begin{array}{l}\text { Zizyphus mauritiana Lam. } \\
\text { RHAMNACEAE } \\
\text { RA } 128\end{array}$ & Bayar & S & Fruit & Used to cure hotness of body and stomach problem. Fruits are edible. \\
\hline
\end{tabular}

documentation of this knowledge and biochemical analysis (i.e photochemical study) of the documented plant species and ecological study of the particular medicinal plant is also essential to check the reliability and validity of current finding and to know their diversity as well. Emphasis should also be given to identification, conservation and cultivation techniques of different species of medicinal \& aromatic plants. Besides that ecological study of the forest vegetation helps for the conservation and utilization of the forest resources in its optimum capacity.

\section{ACKNOWLEDGEMENTS}

I am thankful to the local resource person for sharing valuable information's on plants and plant resources and kind co-operation during this study. I am greatly indebted to my teacher Dr. Bharat Babu Shrestha and my friend Mr Lila Nath Sharma for their encouragement and valuable suggestions to accomplish this research work.

\section{REFERENCES}

Acharya, R. and Acharya, K.P. 2009. Ethnobotanical Study Of Medicinal Plants Used By Tharu Community Of Parroha VDC, Rupandehi District, Nepal. Scientific World 7(7): 80-84.

Ale, R., Raskoti, B.B. and Shrestha, K. 2009. Ethnobotanical Knowledge of Magar Community in Siluwa VDC, Palpa District, Nepal. Journal of Natural History Museum 24:58-71.
Anonymous. 2009. Gulmi Darpan. District Development Committee. Gulmi. 95p (Text: Nepali).

CBS. 2002. Population of Nepal: Caste/Ethicity, Mother Tongue and Religion (Western Development Region). Central Bureau of Statistics, Thapatahli, Kathmandu, Nepal.

Chaudhary, R.P. 1998. Biodiversity in Nepal (status and conservation). S. Devi, Sharanpur (U.P.), India and Tecpress Books, Bangkok, Thailand. $289 \mathrm{p}$.

Ghimire, S.K., Sah, J.P., Shrestha, K.K. and Bajracharya, D. 1999. Ecological study of some high altitude medicinal and aromatic plants in the Gyasumdo valley, Manang, Nepal. Ecoprint 6(1): 1725.

Ghimire, S.K. 2008 . Sustainable harvesting and management of medicinal plants in the Nepal Himalaya: current assues, knowledge gaps and research priorities. In: Medicinal plants in Nepal: an Anthology of Contemporary Research (P.K. Jha, S.B > Karmacharya, M.K. Chhetri, C.B. Thapa \& B.B. Shrestha, eds.) pp25-44. Ecological Soc

GoN. 2008. Samudayik ban upabhokta samuhaharuko anugaman tatha nirichhan pratibedan. Government of Nepal, Ministry of forest and soil conservation, Department of forestry, District Forest Office, Gulmi. 87p (Text: Nepali).

Hara, H., Stearn, W.T. and Williams, L.H.J. 1978. An enumeration of the flowering plants of Nepal, Vol. 1. Trustees of British museum (Natural History), London.

Hara, H. and Williamns, L.H.J. 1979. An enumeration of the flowering plants of Nepal. Vol. 2. Trustees of British Museum (Natural History), London.

Hara, H., Charter, A.O. and Wiliams, L.H.J. 1982 An 
enumeration of the flowering plants of Nepal. Vol.3. Trustees of British Museum (Natural History), London.

Joshi, A.R., Shrestha, S.L. and Joshi, K. 2003. Environmental Management and Sustainable Development at the Crossroad. Ankus, Kathmandu, Nepal.

KC, B.M. 2006. Utilization of Plant Resources and Environmental Justice in Resunga, Gulmi District : a case study. M.Sc. Dissertation. Central Departmant of Botany, Tribhuvan University, Kirtipur, Kathmandu, Nepal. 178p.

Khadka, U>R> and Pokhrel, C.P. 1999 . Studies on vegetation composition and resource use pattern in Resunga (Gulmi). Report submitted to the University Grant Commission (UGC), Kathmandu, Nepal. 23p.

Kurmi, P.P. and Baral, S.R. 2004. Ethomedicinal uses of plants from Salyan district, Nepal. Banko Jankari 14 (2):35-39.

Mahato, R.B. 1998. Notes on some plants of ethnobotanical importance from Palpa district. Journal of Tribhuvan University 21 (1): 71-76.

Manandhar, N.P. 1980 . Medicinal plants of Nepal Himalaya. Ratna Pustak Bhandar, Kathmandu, Nepal.

Manandhar, N.P. 2002. Plants and People of Nepal. Timber Press Portland, Oregan, USA, Vol. 1. 599p.

Manandhar, L.N. and Chaudhary, R.P. 1992. Medical Plants and their traditional use by tribal people of Saptari district, Nepal. Proceedings of first national botanical conference Aug. 11-12, Kathmandu, Nepal.

Nepal, L.R. 2003. Historic, Religious And Biological Place Resunga, Resunga Development Plan. District Forest Office, Gulmi. 36p.

Panthi, P. 1984 Resunga sambandhi chinari. District forest office, Gulmi. 95p (Text: Nepali).

Pei, S.J. 2005. Ethnobotany and Modernization of Traditional Chinese Medicine. In Himalayan Medicinal and Aromatic Plants, Balancing, Use and Conservation (eds. Thomas, Y., Karki, M., Gurung, K. and Parajuli, D.), Ministry of Forest and Soil Conservation, HMG, Nepal.

Polunin, O. and Stainton, A. 1984. Flowers of the Himalaya. Oxford University Press, New Delhi, India. 545p.
Poudel, S. and Gautam, C.M. 2008. Studies on Ethnomedicine of Magar Community in Dhading District, Central Nepal. Department of plant Resources, Thapathali, Kathmandu, Nepal. Bulletin of Department of Plant Resources No. 30: 80-86.

Poudel, S., Bhattarai, N. Yogi, P.N. and Karmacharya, R.B. 2010. Ethno-medicinal plants Used by the People of Argha VDC, Arghakhanchi District, West Nepal. Department of plant Resources, Thapathali, Kathmandu, Nepal. Bulletin of Department of Plant Resources No. 32: 73-85.

Press, J.R., Shrestha, K.K. and Sutton, D.A. 2000. Annotated checklist of the flowering plants of Nepal. The Natural History Museum, London.

Rai, S.K., Subedi, S. and Mishra, S. 2004. Utilization Pattern of medicinal plants in Thumpakhar, Village Development Committee, Sindhupalchok, Nepal. Botanica Orientalis 4 (1): 75-78.

Rai, S.K. and Pokhrel, M. 2006. Ethnobotanical Survey of Medicinal and Aromatic Plants of Chandannath, Depalgaun and Garjangkot Village Development Committees (VDCs) of Jumla, Mid Western Nepal. Bulletin of Department of Plant Resources No. 27: 16-20.

Shrestha, A., KC, B.M. and Thapa, C.B. 2004. Ethno-medicinal uses of plants among the Kumal community in Chirtungdhara, Palpa, Nepal. Botanica Orientalis 4 (1): 59-62.

Shrestha, P.M. and Dhillion, S.S. 2003, Medicinal plant diversity and use in the highlands of Dolakha district, Nepal. Journal of Ethnopharmacology 86: 81-96.

Singh, S. 2006. Non-timber Forest Products (NTFPs) of Nepal Used in Pharmaceutical and Related industries. Department of Plant Resources, Thapathali, Kathmandu, Nepal. Bulletin of Department of Plant Resources, No. 27:51-56.

Subedi, R.R. 1998 . Historical, Glimpse of Gulmi. Kiran Pustakalaya, Tamghas, Gulmi (Text : Nepali).

Stainton, A. 1988. Flower of the Himalaya: a supplement. Oxford University Press. New Delhi, India.

Ved Prakash. 1998. Indian medicinal plants- current status-I: Enthnobot 10:112-121. 